\title{
ANTHROPOLOGICAL INQUIRY INTO THE FORCE OF THE EMOTIONS IN THE FAMILY OF MAN: AN OVERVIEW
}

\author{
JAMES W. FERNÁNDEZ ${ }^{1}$ \\ University of Chicago
}

AвSTRACT: The argument of this essay, in its concern with human emotion, moves (an important word for its argument) in two directions and through three sequential sections. We can imagine this movement as a «zooming out» and a "zooming in» while thinking about and inspecting the emotionally entangled cultural creatures that we humans are in our social lives in culture.

As appropriate to a general anthropology and as appropriate to an introductory statement we move out almost to maximal focus and consider our emotionality in terms of our neoteny, which is to say our long dependency on others as the entirely social animals that we are.

Next readjusting our focus we move in upon the discipline of anthropology. We have made this movement towards, or many of us anyway have made it, importantly under the pressure of the feminist critique which, itself, has struggled to get out from under the gendering of our professional understanding by which gendering reason was assigned to masculinity and emotion to femininity. Thirdly in our sequential refocusing, and as an almost inevitable expression of our culture of individualism - we zoom in upon the career of the present author. We see him as over forty years he has moved from a formal, Cartesian - like, vectoral structuring of the emotional vicissitudes of social life, deductive in nature by attempting a deeper understanding of ethnographic responsibility to the emotions he has experienced in his various fieldwork in Africa and Europe.

Finally in conclusion we zoom out again, jumping scales again, by taking up the inescapable necessity, at a time of globalization, of considering the emotions at play in national and international contexts.

KEYwORDs: dependency theory, emotionality, life histories, moral sentiments, transcendent humanization, vicissitudes.

\footnotetext{
1 jwf1@uchicago.edu
} 
Resumen: El argumento de este ensayo en lo que concierne a las emociones humanas se mueve (importante palabra aquí) en dos direcciones y a lo largo de tres secciones secuenciales. Podemos imaginar este movimiento como un zoom hacia el exterior y un zoom hacia el interior, mientras pensamos e inspeccionamos a criaturas culturales emocionalmente embargadas que somos los seres humanos en nuestras vidas sociales en la cultura. Como algo apropiado para una antropología general y para una proposición introductoria nos movemos hacia fuera casi hasta el máximo foco y consideramos a nuestra emocionalidad en términos de nuestra neotenia, que es lo mismo que hablar de la larga dependencia que tenemos de los otros como animales completamente sociales que somos. A continuación de reajustar el foco nos movemos hacia el interior de la disciplina antropológica. Hemos hecho este movimiento (o muchos de nosotros de todos modos lo hemos hecho) significativamente bajo la presión de la crítica feminista que, en sí misma, ha luchado por salir de la generización de nuestra comprensión profesional por la cual la razón de género fue asignada a la masculinidad y la emoción a la feminidad. En tercer lugar, en el cambio de foco secuencial, y casi como una expresión inevitable de nuestra cultura de individualismo dirigimos el zoom hacia la propia carrera del autor. Le vemos cómo en 40 años se ha movido desde una estructuración formal, cartesiana, vectorial de las vicisitudes emocionales de la vida social, deductiva en su naturaleza, que intentaba una comprensión más profunda de la responsabilidad etnográfica, a las emociones que él ha experimentado en sus varios trabajo de campo en África y en Europa. Finalmente para concluir fijamos el zoom hacia afuera de nuevo, subiendo escalas de nuevo al afrontar la ineludible necesidad, en la era de la globalización, de considerar las emociones en juego en contextos nacionales e internacionales.

Palabras Clave: teoría de la dependencia, emocionalidad, historia de vida, sentimientos morales, humanización transcendente, vicisitudes.

"If the chief part of human happiness arises from the consciousness of being beloved, as I think it does, these sudden changes of fortune seldom contribute much to happiness»

Adam Smith The Theory of Moral Sentiments

\section{1. «Tears Not so Idle Tears»: Some Available Generalizations On Phylogenetic and Comparative Emotionality}

For the anthropologist inevitably anchored in all things human there are several introductory and contextualizing references to our subject matter in this 
colloquium, «The Place of the Emotions in Living Culture» ${ }^{2}$. First of all there is the resonance of this title with Darwin's classic tome, The Expression of the Emotions in Animals and Men, (1877) and secondly there is the matter of all the available commonplaces we are aware of, the topics or topoi as the ancients called them, or «El Bosque de los Tópicos». as our late Spanish colleague in historical anthropology, Julio Caro Baroja, called them, through which we have to make our way seeking some relief in a clearing in those woods of human life and by which so often we understand the different place and presence of the emotions as we compare peoples and cultures.

In respect to the first matter Darwin puzzled over the almost complete lack of "emotional weeping» among other animals and particularly other primates. The copious flow of tears which humans everywhere emit in certain, mainly often enough in culturally influenced social circumstances, seemed to him and for subsequent students of the phenomena to be a function of the extended infancy and childhood of humans, a state of dependency well served by the distress and need signals of tearful crying as guarantors of the required sympathetic attentions of put-upon adults. And, of course, even adults do not escape the power of tears. Even strong men cry as did our former President George H. W. Bush recently in thinking about the fate of the Bush legacy after his older son George W. rather than his preferred and wiser son Jeb, through a trick of political fate, ascended to the Presidency! No doubt these father's tears had some anchorage in a father's memory of how his sons had handled their childhood dependences. The exacted sympathies of this long period of infant-child dependency, and human neoteny in general, gives to all human societies, with variable expression of course, a quality of expressed emotionality that other animal societies do not possess ${ }^{3}$. We are tearful animals, for crying out loud, and one might add, not only the frailties of our transitory and mortal natures but, as the homo faber we are, our planful, but not planful enough inventiveness, our too frequent role as the incompetent sorcerer's apprentice, in possession of powers we only dubiously control, has all too often given us something to cry about!

While it may bring tears to the eyes to think of our unrequited dependencies upon one another, to say it in that way addresses the second part of the theory

2 Una primera versión de este artículo fue expuesta en Yale 2012. (Nota de los editores).

3 Of course, crying needn't be accompanied by tears. But the fact that prolonged dry expressive crying for attention is detrimental to the mucous membranes and exposes the organism to disease may help explain tears as a copious naso-lacrimal wash and mucal passages restorative! 
of "emotional weeping.» We weep not only out of unattended discomfort over extended years of dependency but out of our social natures. We weep because we are not only highly dependent animals we are, it follows of course, by reason of that dependency, highly social animals. This was the emphasis in the theory of the British Social Anthropologist A. R. Radcliffe Brown concerning obligatory ceremonial weeping among the Andamanese Islanders.(1932) Weeping in that Society in Brown's analysis has a pronounced social rather than personal need function nature ${ }^{4}$.

«I regard it as being the affirmation of a bond of social solidarity between those taking part... arousing the sentiment of attachment... serving to renew social relations where they have been interrupted... or weakened or modified... In all instances we may say the purpose of the rite is to bring about a new state of the affective dispositions that regulate the conduct of persons to one another, either by reviving sentiments that have lain dormant or producing a recognition of a change in the condition of personal relations» $(1932: 245)$.

We may perhaps relate to this social obligation phenomenon by recalling the tendency of parades and the passing of one's country's flag to produce tears in bystanders although otherwise they are experiencing no personal discomfort or dejection that requires attention. It may have been because of such emotional loss of independency of judgment in parades that Einstein, well acquainted with and forewarned by the burgeoning parades of National Socialism in his native Germany of the thirties, was caused to warn against attendance at parades much less participation in them. Those social tears, we might call them, caused in we social animals by the formalized massing of our fellows, tears of recognition of our social natures and identities perhaps, were, for Einstein, emotions too volatile and too easily manipulated by political interests. His century, his people, and he himself in Nazi Germany, had suffered many times over from the fateful consequences of mass emotion, from the passions of the crowd stirred up in military parades. We have a lot to cry about when we think about the horrors of the last century past through which most of us gathered here have lived.

Indeed, early on in the Century of Total War, as it was called, crowd behavior and the manipulated emotions of the crowd became a subject of scientific

${ }^{4}$ See also in this regard Schieffelin, Edward, (1976). The Sorrow of the Lonely and the Burning of the Dancers. New York: St. Martin's Press. 
inquiry and we have from that period, Gustav le Bon's «The Crowd $»^{5}$, one of the classics of social science. Le Bon, unlike Einstein, was positively interested in crowd behavior and how it might be put to use for political especially military purposes. It was a text studied closely by the French General Staff and consequently also by the German General Staff. Subsequently it fell into the hands of the Nazis maximally astute in manipulating crowd emotions, in bringing tears to the eyes of German patriots, making them conscious in the positive sense of their dependency upon the state. One cannot resist commenting on Le Bon's nationalizing of the emotions It was one of his observations that southern European, that is Latin Crowds, were much more volatile and manipulate able than northern European, Germanic Crowds. The Nazi's, perhaps, put that prejudicial commonplace to the test (and to rest) with appalling negative results!

Nevertheless, whenever one hears that extended, exultant cry of «Goooool» of Latin football announcers one is very likely to be put in mind of Gustav le Bon's ideas of Latin emotionality! Not exactly a "cri de coeur", still that vociferation and whoop of glee in a southern country as a ball enters a net and in an exultation of partisan passions raises the national identity question as regards emotionality.

Of course, it was not just Le Bon's quasi «scientific opinion» but a well known European commonplace that southerners are more emotional than northerners and studies of the north-south continuum repeatedly reveal that stereotype as well as the Aristotelian proportions attendant to it $^{6}:$ North/South:: mind/ matter:: head/heart:: calculation/ expression:: male/ female:: reason/emotion. The distribution of emotionality according to latitude was from fairly early on a shibboleth of geographical determinism: resulting in goose-fleshed, chappedskinned ice people of the north, on the one hand, parchoderms, cold quiet and calculating, never getting mad but getting even and moistoderms, sweaty skinned, nice people of the south, on the other, hospitable even lovable but unstable, voluble, emotional, arousable and irascible easily angered and easily defeated by patient, long but quietly suffering septentrional strategists. For many emotions can hardly be discussed independent of geography let alone of

5 Le Bon, Gustave (1897). The crowd: a study of the popular mind. London: Unwin.

${ }^{6}$ Cf. Fernández, J. W. "The North-South Axis in European Popular Cosmologies and the Dynamic of the Categorical», in Michael Herzfeld (ed.) «Provocations of European Ethnology,» American Anthropologist, Vol. 99. (4): pp. 713-730. But the north-south distribution of emotionality is not just European. See also Levine, R. and CampbelL, D. (1972) Ethnocentrism: theories of conflict, ethnic attitudes, and group behavior. New York: Wiley. 
gender. This latter observation is made clear by a long history of «metonymic misrepresentations» that have assigned to women the emotional role, the hysteric role, and the more unsettled and unsettling humors and organs of the body, in particular the womb.

Indeed, regarding the commonplaces, or topicos to use the Spanish term, one can readily map geography upon the body and one, thus, moves south from the cool head of the north to the warm heart of the midi to an unstable and overheated womb, the wayward loins, way down south there. The unemotional person is a cold person indeed, all head and no heart, with his or her interests well in mind, and above all a master of the passions surrounding the procreative impulses. He keeps his eye focused on the north star and is cautious about "going south» in his preoccupations and in human relations.

If geography and gender have been ever present determinants of commonplace thought about the distribution of the emotions in the world surely also is culture. The age of exploration was full of colonialist observations on the emotional natures of the people encountered... The people of my first field trip in Africa, the Fang, were valued by colonizing officials because though relentless when finally angered they were, so the colonial attitudes went, cool and calculating participants in the colonial enterprise in contrast to the volatile and untrustworthy coastal peoples victims of their own emotions. And the people of the most recent field trips, the Asturians, are frequently, in respect to commonplaces, contrasted in respect to emotion with Andalusians a contrast particular present in a jocular poetic exchange between an Asturian and an Andalusian published in the late 19 th century ${ }^{7}$.

In any event our title here is intended to evoke something of the culture of the emotions as well, to be sure, the relation of the emotions to the goal gradient experiences we experience in working through our human projects in this world and seeing to their management and completion in social life. For emotions are not constant in daily life, that is to say they rise and fall according to the state of our projects with which and with whom we have always a tentative relationship and involvement never being perfectly sure of bringing them to completion. As is widely recognized sports is a simulacrum of life itself although necessarily con-

7 Fernández, J. W.: «Andalucia on Our Minds: Two Contrasting Places in Spain As Seen in a Vernacular Poetic Duel of the Late 19th Century». Cultural Anthropology. Vol 3. No. 1. pp. 21-35. 1988. 
ducted by much stricter rules. And soccer football may be more of a simulacrum yet when compared with the high scoring American sports, given the relative infrequency with which goals are scored in European football and the relative infrequency which in life itself we have the sense of fulfilling a project by definitively and unambiguously putting the «ball» in the "goal», so to speak There is a lot of pent up emotion in those projects in life in which goals are few and far between. That exclamatory "gooool» seems to express that fact well. It is hardly present in sports in which scoring is very frequent. We associate it with Latin emotionality to be sure but it has a meaning that goes deeper than that into the comparative pacing of success in the human enterprise and its projects, in the putting the ball into the gol or failure to do so.... in the vicissitudes of culture as it were!

\section{An Overview of the Anthropological Study of the Emotions and The «Sensorium» of their Expression}

Let me say something more, although briefly and in something of an overview, about anthropological work on the emotions before we focus on a problem or two with an important emotional component in this author's present anthropological project. This is a complex subject with much literature to be consulted. We will treat it cursorily but I think accurately. In general it is said that it is only recently that anthropology has paid much attention to the emotions and probably mainly under the influence of the feminist critique of the repression of the reality of the body in the reason oriented work of the patriarchal predecessors, more interested as they were for many years in formalizing structures and vectored functions of interaction and architectures of understanding of the over abundant field data in society and culture. This generalization may be true enough but one has to recognize that much earlier in the teens and twenties in American Anthropology there was an effort to get more of the atmosphere and coloration of life as lived in society and culture, which is to say the emotional tenor of things, into the rather stark and wooden ethnographic accounts then characteristic of ethnographic work. It is of interest that it was a well to do (but professionally respected) patroness of the discipline of the time, a woman anthropologist, Elsie Clues Parsons, who urged more lifelike descriptions of the people being investigated and of what it was actually like for them to live in and through their cultures. This resulted in the volume to which almost all notable American Anthropologists of the period contributed, American Indian Life (1922) .

\footnotetext{
${ }^{8}$ Parsons, E. C, (ed.)(1922). American Indian Life. New York: Huebsch.
} 
One also ought to mention, as a precursor Hildred Geertz'1950s work resulting in the short monograph The Vocabulary of Emotion: A Study of Javanese Socialization Process (1959) examining Balinese emotion terms as essential ethnographic data in understanding the emotional animus present in Balinese social and cultural reproduction. In general up to that time anthropologists had been interested in such things as trait distributions or culture contact and acculturation, the first world-third world interactions in strategic terms of power relations of domination and subordination, and in terms of the structures of thought rather than in emotional terms or by reference to the vicissitudes of the emotions themselves. The more subtle emotional elements involved in culture contact, an acculturation between colonial authority and colonized obedience, sentiments of domination and subordination especially, were certainly recognized and referred to but usually not studied in specific terms and certainly not intentionally evoked in so many words in ethnography. The inevitable emotionality of the subjugation of colonization and the colonial situation tended to be taken for granted.

Parson's request, in any event, resulted mainly in an attempt at vignettes, that is individual portraits, for the most part quite wooden in characterization. Not a great deal was said about the emotions or emotional states of the characters portrayed in the vignettes that appeared in that volume. But that volume was influential in stimulating the subsequent life-history studies in anthropology where the focus on the individual's experiences in culture inevitably directly or indirectly, explicitly or implicitly evoked the emotional texture of that subject's life in culture, and particular in colonized cultures which were mainly the cultures available and subject to ethnographic investigation by early anthropology.

An exception to this negligence is the degree to which the emotionalities of colonization were inevitably present in the taking or inspiring of life histories in American Anthropology. Parson's American Indian Life was followed not long after by the first of the important life histories produced over the years in the American tradition, Paul Radin's Crashing Thunder: The Autobiography of an American Indian (1927). Radin was able to stimulate in his autobiographee, Sam Blowsnake (Crashing Thunder), accounts of challenging situations, with evident emotional implication for the autobiograffee, of the kind lacking in previous ethnography more interested in the aspects and catalog able traits of culture than in the vicissitudes of individual lives, whether recounted by anthropologists or by natives themselves. But if there was ever an account of vicissitudes and of life's emotional rollercoaster of climax, anti climax, desolation feelings of 
guilt honestly recalled, deep regret, attempted retribution and reanimation and ultimate conversion it is the life as recounted to Radin by Crashing Thunder, Sam Blowsnake. Although a variegated life account, told in a relative matter of fact manner, the reader can hardly escape appreciating what must have been the considerable emotionality, if suppressed in the presence of the ethnographer, attendant to recounting his life experiences.

Life history studies subsequently became an important part of American anthropology and the list of greater life histories in which the vicissitudes, that is the emotionalities of daily life are put before the reader is long indeed. Not so long after Crashing Thunder, John Neihardt produced Black Elk Speaks (1932) a truly absorbing and in many places moving account of the last days of the Lakota Sioux, first in their victorious confrontations with the American Army at the battle of the Little Big Horn (1876) and later in the American Army's disastrous massacre of the Sioux people at Wounded Knee (1890). In this account, as well, the relative matter of fact recounting of these events of high emotionality, for both an Indian and American reader at the time and long after, may not make the case for special interest in evoking the emotions in anthropological documents. But Black Elk's account of his and his friend's courtship experiences, High Horse's Courting, and the love sickness and blind desire that accompanied the character's obsessive passion surely does (2008: Chapter 6).

As a general observation one might argue for anthropology that it was women anthropologists who have in more recent decades, and animated by the rise of feminist sensibilities deeply questioning patriarchal attitudes and accompanying ethnographic limitations on tracing the tenor and vicissitudes of everyday life, who have focused more intently on life's emotional contours in greate detail and with more insight than heretofore constrained and challenged by gender stereotyping and the stereotype of emotionality as a woman's thing and gender studies managed these contours, these vicissitudes, of «life writing» better and with more insight than men. Two moving life history studies of this quality may be instanced: Marjorie Shostack's Nisa: the Life and Words of Kung Woman (1981), and Ruth Behar's Translated Woman: Crossing the Border With Esperanza's Story (1993). These are exemplary works in capturing the emotional

9 This great life history originally published in 1932 had come out in a number of revised editions by Neihardt 1961 and 1972. The Premier Edition published by SUNY Press in 2008 is much enriched by the informed annotations of Professor Raymond DeMallie, anthropologist and Lakota Sioux authority. 
world of women: the one capturing the emotional tensions of a woman engaged in Kalahari survival on the narrow margin with a considerable degree of gender equality but amidst wayward and not fully reliable men on the one hand, and, in the other, capturing the ways and woes of a wise woman in a very male dominated, often enough by force, society. In both accounts the emotionality of male female relations are sharply dawn and commented upon in a heretofore uniquely convincing way.

But we must here also warn ourselves as well against too facile gender generalizations, and too readily confirming that old and all too comfortable commonplace long present in our discipline; the old platitude that men ethnographers are to women ethnographers as the study of reason is to emotion! Just to temper such generalization I would like to mention two of my favorites ethnographies for the Mediterranean World as far as grasping the emotional tenor of life in culture is concerned: Donald Pitkin's. The House that Giacomo Built: History of an Italian family, 18981978 (1985) and Sally Cole's Women of the Praia: Work and Lives in a Portuguese Coastal Community (1991). Pitkin's small book a close account of several generations of laboring men and women, mainly of one extended family, of the southern Italian countryside and their frequently frustrated attempts to improve their lives while maintaining harmony and inclusive affection among themselves. Pitkin, himself is a relative low key ethnographer, but his ethnography is about as moving account of the evolving vicissitudes of courtship, parenthood, grandparenthood and above all the arduous search for property and prosperity as one is likely like to find in the literature regardless of the gender of the author Pitkin was particularly determined as he himself says and as regards this evolving family's life «to evoke their sentiments of what has befallen them» generation after generation (1985:7). For any reader the vicissitudes quietly recounted in this study are moving indeed.

Cole for her part, in this feminist inspired text, a sensitive collection of stories from the fisherwomen with which she worked, is equally evocative of the emotional vicissitudes of their lives. But her work also enables her to comment insightfully and critically on models of Mediterranan social life that had been perennially favorite topics of male anthropologists in Mediterranean Studies; the dynamics of Honor and Shame in gender relationships ${ }^{10}$ and reproduction and the constricting place of envy in social interaction and as an obstacle

10 Peristiany, J.G. (ed.) (1966). Honour and Shame: the Values of Mediterranean Society, Chicago: U. Chicago Press. 
to the obtaining of community solidarity. In respect to the former, examining Honor and Shame from a woman's point of view, Cole shows now limited and constructed this model of gender relations defined mainly in terms of sexuality is in the full context of fisherwomen's working lives and consequent emotions. In respect to envy, Cole shows how much the supposed presence of this preoccupying emotion, and metaphor for the politics of social life in women's lives has been a consequence of recent commodification and industrialization, in fact, often enough a distraction in ethnographic understanding from these class and work-a-day issues. So this work is at the same time a trenchant and perceptive analysis of the evolving social political and economic structure of life in these villages, the central vicissitudes of the fishing life way. There is a lot of emotion in the lives of fisherwomen for the unpredictability and uncertainties of that mode of production are well known and fish-wives have a long standing reputation for a tough intensity of emotional expression in social interaction. But the stories Cole gathers goes beyond these generalities into the various dialectical levels of her informants lives as they are in dialogue with themselves, their communities and with the changing times and cultural trends. As for Pitkin's longitudinal life studies over the several generations: the emotionality bound up in house building and house living, the central trope of his work and his informants efforts at improving their lives and house is also well known. It is a kind of foundational emotion, for family homes are the shaping structures of the earliest emotions and moving from them and moving into them are very arguably the primary motions with the deepest emotional meaning.

With the coming of interpretive anthropology in the mid seventies and especially with feminist anthropology in its wake in the eighties the emotional tone of social life was addressed more directly if not, as in the case of Hildred Geertz, by drawing up nuanced lexicons of the panoply of appropriately named emotions to be employed in the socialization of children. Still it was directly addressed through careful attention to the life stories of informants, life histories in small. The analytic preoccupations of acculturation, structuralism and Marxism as replaced by the emphasis on ethnographic detail of interpretivism and the critique of the previously gendered understandings of the social political realities of community life led to ethnography increasingly evocative and more directly involved with, in one way or another, the emotionality of daily life. But many subsequent anthropologists have been attentive both to the sensual and thus collaterally to the emotional contours of social life, some to the point of arguing that it is a primary responsibility of anthropological ethnography to address as we can the tenor not just the structure of social life in culture. 
A signal contribution to the focus on the study of the emotions was the publication in 1986 in the Annual Review of Anthropology of a Review Article by Catherine Lutz and Geoffrey M. White on «The Anthropology of the Emotions ${ }^{11}$. It showed and testified in one place to how much work had been afoot among anthropologists in the previous decade and a half on the emotional content of culture. Lutz' previous fieldwork in Micronesia had sought to track the vicissitudes of sentiment in daily social life. ${ }^{12}$ Attunement to the presence and fluctuations of the emotions in society was not mere sentimentality but could tell us important things about how political practices worked the emotions of constituents and how they captured the imagination in favor of particular political postures.

Speaking of capturing the imagination, however, there were several absorbing precedent accounts not the least being the 1970's ethnography of Jean Briggs, Never in Anger ${ }^{13}$ a study infused with a constant tension between the ethnographer's mode of anger management and that of her Eskimo hosts. In a different vein but treating also of the presence of the emotionality, and particularly the recognition of anger in fieldwork and its absence in much ethnography was the utterly absorbing account by Renato Rosaldo of the deep anger provoked in him by his wife's accidental death which in turn produced his insight into the Ilongot rage at loss, and a further understanding, still, of the cultural shaping of emotions in general, «Grief and a Headhunter's Rage: On the Cultural Force of the Emotions» $(1984)^{14}$ Renato's essay was, undoubtedly the memorable and most resonant clarion call to anthropological sensitivity in, and attention to, the emotional contours of life in culture. Ruth Behar's «Death and Memory: from Santa Maria del Monte to Miami Beach» ${ }^{15}$ like her Translated Woman treated

11 Annual Review of Anthropology. 1986. 15:405-436.

${ }_{12}$ Her Unnatural emotions: everyday sentiments on a Micronesian atoll and their challenge to western theory, (1988) tested the notion of universals in human emotion, and her subsequent work with others on the «Politics of emotion» has provided a fulcrum for the investigation of the uses and provocations of calculated and constructed emotionality and discourse about emotion as categorizing practices important in justly or unjustly distributing goods in society, between men and women, between rich and poor, between ethnic groups and between classes.

${ }^{13}$ Briggs, Jean (1970). Never in Anger: Portrait of An Eskimo Family. Cambridge: Harvard Univ. Press.

${ }^{14}$ Rosaldo, Renato (1984). "Grief and a Headhunter's Rage: On the Cultural Force of the Emotions," in Text Play and Story: The Construction and Reconstruction of Self and Society. E. M. BRUner, ed. Washington: AES. pgs. 178-195 (Also in Culture and Truth).

15 Behar, Ruth (1991). "Death and Memory: from Santa Maria del Monte to Miami Beach.» Cultural Anthropology, Vol.6 No.3. August, pp. 346-384. 
above has also been a memorable contribution to the recognition of the emotions of loss and anger in daily life.

Insofar as feeling tone and the various sensory feelings themselves are part integral to the experience of the emotions, collateral with these eighties work oriented to emotional movement was work was emphasis on fuller attention to the cultural sensorium, the tasting, touching, hearing, smelling, elements in culture as a necessary compliment to the previously too exclusive attention to the mainly observational or visual parts of culture. Notable and pioneering here was the work of Feld, Howes and Stoller ${ }^{16}$ and also in respect to the previous dominance of observation and the over concentration on visualization and the over dependence on sight and seeing see Tyler (1984) ${ }^{17}$.

\section{What It Means to be Moved. Vectors of Emotional Movement in African Religious Movements: (Out of Oneself and Into the Other or Out from the Other Into Oneself)}

Move: From the latin e+movere, to move out of.

- A migration, a transference, an agitation or disturbance of state whether physical or social.

- Any such departure from the usual calm state of the organism.

We turn now in this tertium quid to address the place of the emotions in some grounded work of ethnography and ethnologic interpretation in the work of the present author. Most importantly a sea change in his approach to understanding the meaning of emotional movement. From the early sixties my approach was influenced by a reading of the vectored analyses found in a popular social psychology theory of the period labeled the «semantic differential» ${ }^{18}$. In

16 Feld, S. (1982). Sound and Sentiment: Birds, Weeping, Poetics and Song in Kaluli Expression. Phil: U. Penn Press. Howes, David (1987) «Olfaction and Transition: An essay on the ritual-uses of smell», Canadian Rev. Soc. and Anth. Vol. 24(3), pgs. 398-416. Stoller, Paul (2990) The Taste of Ethnographic Things. Phil: U. Penn. Press.

17 Tyler, S. (1984). "The Vision Quest in the West or What the Mind's Eye Sees.» J. of Anthropological Research, 40,(1): pp. 23-40.

18 Osgood, C. E., Suci, G., \& Tannenbaum, P. (1957). The measurement of meaning. Urbana, IL: University of Illinois Press. 
this particular reading emotions were understood as associated with movement along a three dimensional three vectored quality space in which all organisms operated. This theory understood organismic behavior as motivated by appropriate positioning of itself in a three dimensional quality space: in respect to its power in relation to the power of other relevant entities ${ }^{19}$ in its behavioral niche or quality space, in respect to its activity vis a vis the activity of other entities with which it interacted; and in respect to its goodness, that is in respect to its acceptance or rejection by others in its behavioral niche or quality space. The emotions were understood in this theory as associated with movement in any direction along the three vectors of this three dimensional quality space.- more or less power, more or less activity, more or less goodness!

This early theory was accompanied by ongoing ethnographic research in Africa, in the late fifties and sixties, of seven different religious movements. I was tending to see religious movement, and the emotions associated with the sense of movement, under the rubric of this theory as movement in one's sense of appropriate power, one's sense of appropriate activity and one's sense of goodness. This understanding, however plausible at some very abstract level, and true enough for both frogs and humans, still seemed far removed from the data of the field and, hence, I circulated a "white paper» in the late 1960s among colleagues titled «What It Means to Be Moved» focusing more specifically on the emerging religious cultures of Africa I and others were studying. ${ }^{20}$ Out of this collegial inquiry came an interest in two, rather than three, kinds of emotional vectors associated with the various religious movements I was studying in Africa: the moving experience of ecstatic communion, ecstasis, with religious powers on the one hand and the moving experience of personal possession of or by these powers on the other. I originally understood these as quite contrary vectors where on the one hand, as seemed obvious enough, one leaves oneself and joins in some kind of communion with The Alien Spiritual Other elsewhere, the common experience of ecstasis, and on the other hand, where religious activity concentrates on attracting The Alien Spiritual «Other» into joining or incorporating itself into the practicant, the common experience of possession. In either case the «usual calm state of the organism» was emotionally affected.. Among the some seven

19 By «relevant entity» one would mean any organism that posed a possible threat, or was a possible food source, or was a possible source of protection and cooperation.

20 The interest in the problem of religious movement and emotional movement as a central part of it is seen in a number of papers of the period: "On the Notion of Religious Movement.» Social Research, Vol. 46 (1), pp. 36-72. 1979; as well as «Moving up I he World: Transcendence «in» Symbolic Anthropology.» Stanford Literature Review, Vol 1 (2) pp. 201-226, 1984. 
religious movements in the various parts of Africa studied in those 15 years, 1958 to 1972, the movements most exemplary of these two forms of spiritual communion were, in respect to ecstasis, the Bwiti religion of western Equatorial Africa ${ }^{21}$, and in respect to possession, the Zulu Zionist peri-urban and empty lot worshippers of Durban South Africa. ${ }^{22}$

Ritual in these two religions were intended to either invite the Ancestral Spirits, the Other upon which the religion was focused, to be present and open to ecstatic communion or, among Zulu Zionists, intended to invite the circumambient spiritual power of the Other, to be present in such way as to enable it, by vertiginous rituals, to take possession and often enough replace the persona of the participants. These two vectors of religious experience were accompanied by different emotionalities, the one achieved a kind of draining of personal emotion as the soul, or religious self, left the body in ecstatic movement to, join with or commune more or less quietly or reflectively with the ancestors at the midnight hour. On the other hand Zionism vertiginous rituals taking place in tight circular spaces aimed at a convulsive response giving evidence of the entrance or flow of Spiritual power into the person often enough electrifying or charging him or her up with the high emotionality of this form of communion. What it means to be moved in African religious movements was understood to be fundamentally a two vectored experience: to be moved outside oneself in ecstatic communion with the outside Other, in a word ecstasis, or to be moved inside oneself by inner embodiment of the outside Other, in a word possession.

But, alas, one cannot be long satisfied with these elemental vectors of religious movement when one is an ethnographer who has spent years in the field and has accumulated hundreds if not thousands of pages of field data. In an article on "African Religious Movements" in $1979^{23}$ the three or two vectored approach, though arguably ultimately insightful and, in a certain way, itself good, active and powerful, and even perhaps a set of simplicities on the other side of the complexity of human behavior, was still found wanting and inadequate in respect to the complexities of the ethnography itself, and the dynamics of the emotions it portrayed or suggested For one thing in religious movements of any

${ }^{21}$ Fernández, J. W. (1982). Bwiti: An Ethnography of the Religious Imagination in Africa, Princeton: Princeton Press.

${ }^{22}$ Fernández, J. W. (1973). «Zulu Zionism.» in Man's Many Ways. Natural History Reader in Anthropology, Richard A. Gould, ed., pp. 326-335. New York: Harper and Row.

${ }^{23}$ Fernández, J. W. (1978). «African Religious Movements.» Annual Review of Anthropology, Vol. VII, pp. 195-234. 
complexity it could be shown that though a specific movement was ostensibly dominant in one or the other vector, and thus plausibly characterized as such, it was never exclusively so. Both vectors were present to one degree or another. No religious movement was so simple and decided vis a vis outside spiritual power as to relate to it in only one way.

In this review article, therefore, I sought to anchor answers to the question of «What it means to be Moved» by focusing rather on the abundant field data of the ethnographies, that is, the religious texts I had directly gathered and recorded as religious expressions, exclamations, explanations in which figurations of local religious thought were contained, in short the various metaphors and other tropes expressive of processes of religious revitalization or devitalization which offered insight into the contours of the emotions in everyday life and not only those emotions involved in exceptional moments of possession or ecstasy!

The "path» metaphor widespread in religious practice and particular central and prevalent of use in the religious movement of Bwiti (1982: Chap 17), as "the path of birth and death», (zen abiale ye awu,) offered particular insight into the effort in Bwiti, a religion predominantly of ecstatic emotion as we have said, to maintain congregants in a normal and steady progression towards salvation. It was a metaphor corrective of the tendency of excessive emotion which to lead to the falling away from «the path» and thereby the loss of salvation. The Zulu Zionists, on the other hand, with their vertiginous circular rituals took the final flinging of the body outside the sacred circle as evidence of possession.

What one learns by focusing on the figurations contained in social and religious thought is now complex and multileveled and multivocal social and religious thought and communication can be, and not easily subject to an easily or quickly vectored reading vis a vis the emotions they expressed or engendered. Nevertheless figuration plays, as I have endeavored to have subsequently shown, a central role in both the framing of religious revitalization process ${ }^{24}$ and its progressive stages themselves characterized by different emotionalities. Of particular focus was the emotional signatures of devitalization and revitalization in culture

${ }^{24}$ In, for example, Fernández, J. W. (1986). Persuasions and Performances: The Play of Tropes in Culture, Indiana, and Fernández, J. W. (1991). Beyond metaphor: The Theory of Tropes in Anthropology. 
as particularly evidenced in the imaginative argument accompanying religious reconversion experiences in these religions. Practically all these religious movements articulated as their project and object the passage of their converts from the state of weak or afflicted vitality to a state of the enriched and more vital sense of self in relations to significant others, both natural and supernatural. The complexity and subtlety of those emotional movements vis a vis their sources in the conditions of the local society and culture can the more certainly be grasped, however, by examining the figurations of the local condition as religious figures speak to it in one form or another.

I also in the process of writing this 1978 Review article and reflecting on my field work experiences called attention to the importance of being aware of, often because the special emotionality present in them of «revelatory incidents». These were charged moments in social life of special emotion, either heightened or suppressed, which when analyzed could give us insight into the underlying and moving tensions of the social order. This interest was influenced in part by Victor Turner's work on that quite emotional process of breach, repair and resolution in social order he called "Social Dramas»" ${ }^{25}$. It was also influenced by Lévi-Strauss' focus on the "unwelcome contradictions» in culture which were emotionally charged and which energized mediations and evasions in local folklore, particularly in mythology ${ }^{26} \mathrm{I}$ undertook in ethnographic write up to signal out these specially charged revelatory incidents using them as introductory to specific chapters and as a foreshadowing of the subsequent interpretive analysis appropriate to them, and to their subject matter.

It has been my ethnographic practice, then, to begin each chapter of my ethnographies with these emotionally charged revelatory moments in the company of which we might tease out, subsequently in the chapter, as an explanatory matrix of direct causes and collateral stimuli and motivations, long smoldering aggravations, and precipitating provocations, both antecedent and subsequent to the event itself. The ethnographic challenge of teasing out this matrix of instigations and inspirations moves one a long way from a Cartesian coordinate system with its "precise», even measurable, vectors of power, activity and goodness as modeled in the «semantic differential» approach.

25 Turner, V. (1957). Schism and continuity in an African society; a study of Ndembu village life, Manchester;-Rhodes Livingston Institute-Manchester U. Press.

26 The usual central reference for Levi Strauss' theories of structural mediation and transformation of the unwelcome contradictions of life through myth is «The Story of Asdiwal» (1968). 
Let me give just one instance of a revelatory and emotionally laden moment in my ethnography Bwiti. It introduces Chapter Nine, «The Occult Search For Capacity». (1982: 215-216).

\section{«The Death of Mba Muzwi}

In the early morning hours not long before sunrise of a September night in the threshold of the long cold rainy season, Muzwi Ekwaga came slowly wailing through the village. Villagers were already in that deep and final stage of sleep of which Fang speak. But Muzwi's cry as he passed through the village sank ominously into our reviving consciousness. We awoke struggling to understand what he was saying. He sang keening «I have lost my son, the only son that was left to me, the son that would take my place in the family. I am an old man. Who shall take up my work? I am an old man and he is dead». Finally the wail passed away as the old man entered the forest on the other side of the village with his lantern. He was on his way to Assok Bele to cry the death there. Everyone knew now that Mba Muzwi was finally dead. He had already lain three days as a dead man refusing all food and drink.»

The chapter goes on subsequently describing the incident and, in the analytic part of the chapter itself, seeking to tease out all the many factors involved in the death of this overambitious youth by mesmerized stupefaction: Mba Muzwi's ambitious and adventurous nature, the inability of village life to satisfy, his ambitions, the overbearing power of the elderly age grades, the exploitation of village naïveté by the African and European merchants of occult literature, the still strong traditional belief in the acquiring of a protective and success guaranteeing guardian spirit, evus, with its associated taboos and dangerous possibilities of violation, his arrogance and lack of social solidarity with his own siblings and his ready domination of a benevolent but weak willed father and overly nurturing mother, the failure of Christian Evangelization to make any significant headway with the young! The matrix of ethnographic interpretation of these highly emotional events is surely over determined. The idea of some combination of power, activity and wishes for approbation frustrated may have, indeed, explanatory value but it did not capture on the ground or on the death bed, as it were, the living culture present in this flickering young life and the denouement moment for we villagers of his father's early morning wailing passage through the village! 


\section{Conclusion: The Scales of Moral Sentiments}

This talk has been something of an emotional roller coaster. We have in our inquiry zoomed up virtually to an Archimedean point seeking to briefly survey what might be a biological anthropology of human nature considered at the widest scale as a nature emotionally in need of enduring nurture, as a nature shaped by the long dependency and endless supplication of infancy, of beseech-ment by tears and other forms of otherwise speechless special pleading and petition in favor of inarticulate personal need. And we have zoomed down into the very heart of human emotionality as known to anthropologist, the assuagements and the sufferings of a social being over the realization or frustration of satisfying, that is to say maintaining and nurturing those "empathetic moral sentiments» that Adam Smith postulated, to be the fundamental anchorage of the human condition. We ended inquiry into such moral sentiments at that most intimate level, with the sad loss of a father of his son, among the most empathetic, most important of the always most hopefully loving of social relationships. Intermediate in this roller coaster has been some commentary on the gradual assumption in anthropology of an increasing interest, thanks to meaningful moves brought about by interpretivism and feminism, of a much greater focus on the emotionality of our life in culture and even more subtly, subsequent inquiry into the corporeal sensoriums evoked and most intimately involved in these emotionalities.

But now here in the conclusion we expand once again the scale of emotionality. And this can occur by mentioning something of the authors most recent work, where he has been involved in a study of language revitalization in northern Spain. ${ }^{27}$ This revitalization movement has been and is mainly a reactive effort caused by the gradual replacement over the centuries of one languishing Latin based Romance language, Asturian, by the more dynamic and aggrandizing Romance, Castillian, which has eventually become, for most purposes THE Spanish language. Asturian, was an early if not the earliest romance of political and governmental importance in Spain, since it was along with Latin, the vernacular language of the Asturian court and the popular language of the Asturian kingdom from the $8^{\text {th }}$ to the $10^{\text {th }}$ century. At that early time after the conquest of the Visigoths by the Moorish forces of Islam, Asturias was, with the exception of the very northern parts of Catalonia perhaps, the only parts of formerly Christian Spain not under the control of theses Northeast African Islamic pow-

27 Fernández, J. W. (1998). Campos Léxicos y Vida Cultural N’Asturies. Uviéu: Academia de la Llingua Asturiana. 
ers coming out of the Maegraeb and their establishment of powerful Caliphate and Emirate kingdoms in southern Spain, in the Andalucía or Al Andaluz, of Cordoba, Seville and Granada.

This Asturian language revitalization movement has been mainly the interest and work of academic intellectuals whose parents and grandparents still spoke the Asturian language in the countryside. This struggle to maintain and revitalize a moribund language can also be attended by emotionality and revelatory incidents in which intense emotions can be evoked by the challenges and frustrations of the revitalizers. These incidents may seem far removed from the ultimate experience of loss felt in the case of Mba Muzwi. One is reminded, however, that just as «language death» is a linguistic term in linguistics for the agony of languages which gradually or rapidly lose speakers to the presence of hegemonic forces, such as colonization and/modernization, so there is analogy between the death of Mba Muzwi as a person in respect to the continuity of time, the vital «time binding», in the father/son relation, and the moribund condition of Asturian as a language in respect to the continuity of time that a common language affects in the vital and living relationship between the revitalizers and their parents or grandparents. In either case, though in quite different ways, a violence is being done to the living presence of genealogical, in the cultural sense, continuity. Language loss, language death is also family loss, a rupture in the continuity of genealogy as a matter of intergenerational communication.

Analogy there may be the between the death of a son and the death of a language but, of course, a language involves much than matters of personal or family identity or the identity of some other intercommunicating cluster of minor mainly domestic scale. It involves matters of the identity of a much larger community or self defined group, a province or a kingdom or a nation or nation state. We have spoken little in this talk about the emotions involved with the association of oneself with such much larger communities, provincial or national, though we have seen such identities implicated in Le Bon's study of crowd emotions and Einstein's mistrust in parades flaunting national symbols.

But, of course, the integuments of emotional attachment that characterize these large communities have been intensively studied, most prominently in Andersons now classic study so widely quoted and subsequently written about, 
and in subsequent rethinkings and rereadings, by critically minded others. ${ }^{28}$ As Anderson argues what obtains in these relations of much larger scale is a kind of symbolic communion with others that one can never know as one knows one's family, kin and neighbor. Yet so often it is a communion which entails intense, even self-sacrificing emotion of obligation to national perpetuation, of considerable similarity to the intimate communion and sense of obligation that a family experiences and evokes.

The intense emotions involved at this national and inter nation level of symbolic social relationship have not been the object of our overview here of some developments in the anthropological interest in the emotions. But it cannot be denied that this emotionality and its vicissitudes is, in the present globalizing world, of the greatest importance and increasingly has attracted the investment of anthropological interest. Indeed the historian of anthropology, George Stocking has long argued that though the anthropological focus has been traditionally been on social relationship of small scale, the ultimate context of anthropological work even among primitive peoples once considered as living in autochthony, has been the national states and international negotiations and treaties that directly or indirectly circumscribed and managed their lives as subjugated colonial subjects. For anthropological work of the last hundred and fifty years or more, however small scale in focus, has inevitably been done in the age of and the context of expansive nationalisms and colonialism. ${ }^{29}$ There are deeply emotional issues that arise when we think about relationships in national and international terms particularly when the overarching domination and subordination dynamics of imperialism and colonialism are involved.

Adam Smith argued in his Theory of The Moral Sentiments that all emotions were tied up with the realization or the frustration of social solidarities since for him, as for Aristotle and Hume, man was a social animal with an inherited capacity and appreciation for orderly social life of togetherness with others and an accompanying faculty of sympathy for others which both enabled that orderliness and condemned it where absent. And hence man's emotional life in culture was mainly bound up with the able exercise of or the hindrance and obstruction to these social faculties and capacities. Mankind's moral sentiments were very

28 Anderson, Benedict. (1983). Imagined Communities: Reflections on the Origin and Spread of Nationalism, London: Verso.

29 See especially the STOcкIng edited and collection, (1991). Colonial Situations: Essays on the Contextualization of Ethnographic Knowledge. Vol 7. Madison: U.of Wisconsin Press. 
likely to be exercised, he pointed out over and over again, in the presence of a social disorder in which issues of domination and subordination and the associated emotions, the vary issues of imperialism and colonization in their exercise, became the often enough ignored issues and emotions of everyday life in the field.

These are rather gross high level observations on the emotions inevitably present in the colonial situation in which until recently most anthropologists worked. And they have been most surely present, if not ethnographically most surely as very present moral sentiments involved in the doing and thinking through of anthropology ${ }^{30}$ making of it in the end a "moral science». ${ }^{31}$ Let us end then on these sentiments of moral discomfort that have been part and parcel of anthropological work among «others»!

\section{Bibliography}

Anderson, B. (1983). Imagined Communities: Reflections on the Origin and Spread of Nationalism, London: Verso.

Behar, R. (1991). «Death and Memory: from Santa Maria del Monte to Miami Beach.» Cultural Anthropology, Vol. 6, №. 3. August, pp. 346-384.

- (1993). Translated Woman Crossing the Border with Esperanza's Story, Boston: Beacon Press.

Briggs, J. (1970). Never in Anger: Portrait of An Eskimo Family. Cambridge: Harvard Univ. Press.

Carrithers, M. (2005). «Anthropology as a Moral Science of Possibilities» Current Anthropology, Vol. 46 (3), pp. 433-456.

FelD, S. (1982). Sound and Sentiment: Birds, Weeping, Poetics and Song in Kaluli Expression. Phil: U. Penn Press.

FernándeZ, J. W. (1973). «Zulu Zionism.» in Man's Many Ways. Natural History Reader in Anthropology, Richard A. Gould, ed., pp. 326-335. New York: Harper and Row.

- (1978). «African Religious Movements.» Annual Review of Anthropology, Vol. VII, pp. $195-234$.

30 See Geertz, Clifford (1968). «Thinking as a Moral Act: Dimensions of Anthropological Fieldwork in the New States». Antioch Review 28(2):139-15.

31 Carrithers, M. (2005). "Anthropology as a Moral Science of Possibilities» Current Anthropology, Vol. 46 (3), pp. 433-456. 
- (1979). «On the Notion of Religious Movement.» Social Research, Vol. 46 (1), pp. 36-72.

- (1982). Bwiti: An Ethnography of the Religious Imagination in Africa, Princeton: Princeton Press.

- (1984). «Moving up in the World: Transcendence «in» Symbolic Anthropology.» Stanford Literature Review, Vol 1 (2) pp. 201-226.

- (1986). Persuasions and Performances: The Play of Tropes in Culture, Bloomington: Indiana University Press.

- (1988). «Andalucia on Our Minds: Two Contrasting Places in Spain As Seen in a Vernacular Poetic Duel of the Late 19th Century». Cultural Anthropology. Vol 3. No. 1. pp. 21-35.

- (1991). Beyond metaphor: The Theory of Tropes in Anthropology.

- (1997) «The North-South Axis in European Popular Cosmologies and the Dynamic of the Categorical», in Michael Herzfeld (ed.) «Provocations of European Ethnology,» American Anthropologist, Vol. 99. (4): pp. 713-730.

- (1998). Campos Léxicos y Vida Cultural N’Asturies. Uviéu: Academia de la Llingua Asturiana. 169 pgs.

Geertz, C. (1968). «Thinking as a Moral Act: Dimensions of Anthropological Fieldwork in the New States». Antioch Review 28(2):139-15.

Howes, D. (1987). "Olfaction and Transition: An essay on the ritual-uses of smell», Canadian Rev. Soc. and Anth. Vol. 24(3), pp. 398-416.

Le Bon, G. (1897). The crowd: a study of the popular mind. London: Unwin.

Levine, R. and Campbell, D. (1972). Ethnocentrism: theories of conflict, ethnic attitudes, and group behavior. New York: Wiley.

Lutz, C. and White, G. M. (1986). «The Anthropology of the Emotions». Annual Review of Anthropology. 15:405-436.

LuTz, C. (1988). Unnatural emotions: everyday sentiments on a Micronesian atoll and their challenge to western theory. Chicago: University of Chicago Press.

Osgood, C. E., Suci, G. \& Tannenbaum, P. (1957). The measurement of meaning. Urbana, IL: University of Illinois Press.

Peristiany, J. G. (ed.) (1966). Honour and Shame: the Values of Mediterranean Society, Chicago: U. Chicago Press.

Parsons, E. C. (ed.) (1922). American Indian Life. New York: Huebsch.

Rosaldo, R. (1984). "Grief and a Headhunter's Rage: On the Cultural Force of the Emotions» in E. M. BRuner, ed. Text Play and Story: The Construction and Reconstruction of Self and Society. Washington: AES. pp. 178-195. 
Schieffelin, E. (1976). The Sorrow of the Lonely and the Burning of the Dancers. New York: St. Martin's Press.

Shostak, M. (1981). Nisa: The Life and Words of a !Kung Woman. Cambridge: Harvard Press.

Stocking, G. (1991). Colonial Situations: Essays on the Contextualization of Ethnographic Knowledge. Vol 7. Madison: U. of Wisconsin Press.

Stoller, P. (1990). The Taste of Ethnographic Things. Phil: U. Penn. Press.

Turner, V. (1957). Schism and continuity in an African society; a study of Ndembu village life. Manchester: Rhodes Livingston Institute-Manchester U. Press.

Tyler, S. (1984). "The Vision Quest in the West or What the Mind's Eye Sees.» J. of Anthropological Research, 40,(1): pp. 23-40.

Recibido: 8/05/2013

Aceptado: 12/09/2013 